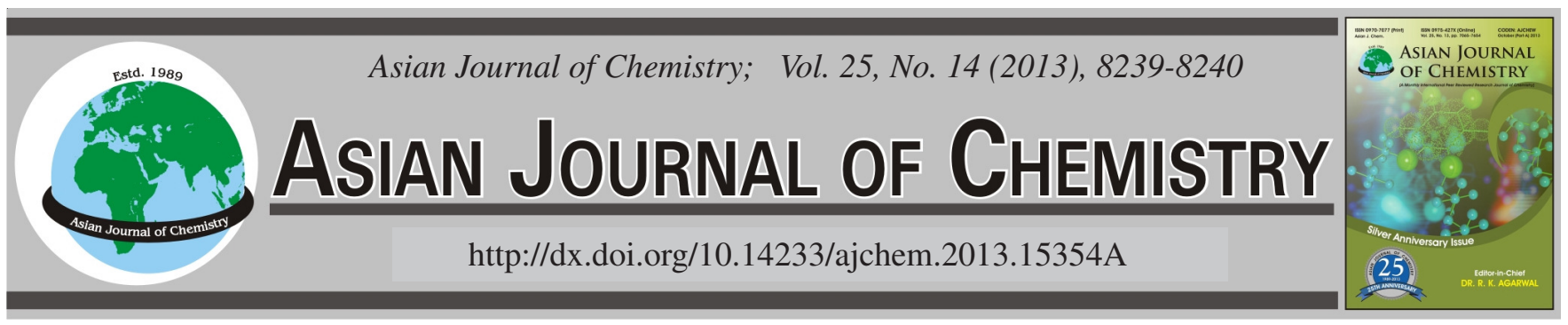

NOTE

\title{
Hydrothermal Synthesis and Crystal Structure of a Ni(II) Complex with Diacetyl Dihydrazone Ligand
}

\author{
JiAn-Hong Bi ${ }^{1, *}$, HuA-Ze Dong ${ }^{1}$ and ZI-XIAN HuAng ${ }^{2}$
}

${ }^{1}$ Deparment of Chemistry and Chemical Engineering, Hefei Normal University, Hefei, P.R. China

${ }^{2}$ Fujian Institute of Research on the Structure of Matter, Chinese Academy of Science, Fuzhou, P.R. China

*Corresponding author: E-mail: bi010101@126.com

(Received: 18 February 2013;

Accepted: 12 August 2013)

AJC-13922

A novel nickel(II) complex $\mathrm{NiL}_{3} \cdot\left(\mathrm{ClO}_{4}\right)_{2}(\mathrm{~L}=$ diacetyl dihydrazone) has been synthesized by hydrothermal method and characterized by
IR spectra and single-crystal X-ray method. The crystal is trigonal, space P-3c1 with unit cell parameters: a =9.5922(5) $\AA, \mathrm{b}=9.5922(5)$
$\AA, \mathrm{c}=15.1871(14) \AA, \alpha=90^{\circ}, \beta=90^{\circ}, \gamma=120^{\circ}, \mathrm{V}=1210.16(14) \AA^{3}, \mathrm{Z}=2, \mathrm{M}_{\mathrm{r}}=600.09, \mathrm{D}_{\mathrm{c}}=1.647 \mathrm{Mg} / \mathrm{cm}^{3}, \mu=1.087 \mathrm{~mm}^{-1}, \mathrm{~F}_{(000)}=624$,
$\mathrm{T}=293(2) \mathrm{K}, \mathrm{R}=0.0474, \mathrm{wR}=0.1276$ for 8580 reflections with $\mathrm{I}>2 \sigma(\mathrm{I})$.
Key Words: Nickel(II) complex, Diacetyl dihydrazone, Crystal structure.

In recent years, the transition metal coordination chemistry of hydrazone Schiff base ligands has got enormous significance due to its diversity of molecular structures ${ }^{1-4}$ and good biological activity of insecticidal, sterilization and weeding ${ }^{4-7}$ and excellent anticancer, catalytic, spectral and magnetic properties $^{1-3,6}$.

Here we report the hydrothermal synthesis and crystal structure of a novel mononuclear nickel(II) complex $\mathrm{NiL}_{3} \cdot\left(\mathrm{ClO}_{4}\right)_{2}(\mathrm{~L}=$ diacetyl dihydrazone $)$.

$\mathrm{Ni}\left(\mathrm{ClO}_{4}\right)_{2} \cdot 6 \mathrm{H}_{2} \mathrm{O}$ was prepared in our laboratory. Diacetyl dihydrazone was prepared by similar procedure in the literature $^{8}$. All reagents were of AR grade and used without further purification. IR spectra were recorded on a Nexus- 870 spectrophotometer. The crystal structure was determined by Siemens SMART CCD area-detector diffractometer.

Synthesis: A mixture of $7 \mathrm{~mL}$ acetonitrile solution of diacetyl dihydrazone $(3 \mathrm{mmol})$ and $14 \mathrm{~mL} \mathrm{H}_{2} \mathrm{O}$ solution of $\mathrm{NiL}_{3} \cdot\left(\mathrm{ClO}_{4}\right)_{2}(1 \mathrm{mmol})$, was carried out in a autoclave and heated to $80^{\circ} \mathrm{C}$ for $48 \mathrm{~h}$. After cooling, the well-shaped scarlet four edges column single crystals were obtained. Yield $37 \%$. IR spectrum $\left(\mathrm{KBr}, \mathrm{v}_{\max }, \mathrm{cm}^{-1}\right): 3420,3320(\mathrm{~N}-\mathrm{H}) ; 1610(\mathrm{C}=\mathrm{N})$; 1090, $623\left(\mathrm{C} 1 \mathrm{O}_{4}^{-}\right)$.

Crystal structure determination: A scarlet colour single crystal $0.45 \mathrm{~mm} \times 0.35 \mathrm{~mm} \times 0.30 \mathrm{~mm}$ was selected for crystallographic data collection at 293(2) K and structure determinated with graphite monochromatic $\mathrm{MoK}_{\alpha}$ radiation $(\lambda=0.71073 \AA)$. A total of 8580 reflections were collected in the range of $2.45 \leq \theta \leq 27.48^{\circ}$, of which 935 reflections were unique with $R_{\text {int }}=0.0193$ and $R=0.0474$ and $w R=0.1276$, where $\mathrm{w}=1 /\left[\mathrm{s}^{2}\left(\mathrm{~F}_{0}{ }^{2}\right)+(0.0643 \mathrm{P})^{2}+1.0654\right], \mathrm{P}=\left(\mathrm{F}_{0}^{2}+2 \mathrm{~F}_{0}{ }^{2}\right) /$ 3 . The maximum and minimum peaks on the final difference Fourier map are corresponding to 0.324 and $-0.496 \mathrm{e} / \AA^{3}$, respectively. The CCDC numbers was 646143.

The atomic coordinates and thermal parameters are listed in Table- 1 and the selected bond lengths and bond angles in Table-2, respectively. Fig. 1 shows diagram of the molecular structure of the complex $\mathrm{NiL}_{3} \cdot\left(\mathrm{ClO}_{4}\right)_{2}$. Fig. 2 shows a perspective view of the crystal packing in the unit cell.

\begin{tabular}{ccccc}
\multicolumn{5}{c}{ TABLE-1 } \\
NON-HYDROGEN ATOMIC COORDINATES $\left(\times 10^{4}\right)$ \\
AND THERMAL PARAMETERS $\left(\times 10^{3} \AA^{2}\right)$ \\
\hline Atom & $\mathrm{X}$ & $\mathrm{Y}$ & $\mathrm{Z}$ & $\mathrm{U}(\mathrm{eq})$ \\
\hline $\mathrm{Ni}$ & 0 & 0 & 2500 & $32(1)$ \\
$\mathrm{N}(1)$ & $2094(3)$ & $800(2)$ & $1770(1)$ & $38(1)$ \\
$\mathrm{N}(2)$ & $2324(3)$ & $1507(3)$ & $960(2)$ & $54(1)$ \\
$\mathrm{C}(1)$ & $3122(3)$ & $431(3)$ & $2072(1)$ & $35(1)$ \\
$\mathrm{C}(2)$ & $4643(3)$ & $807(4)$ & $1617(2)$ & $53(1)$ \\
\hline
\end{tabular}

The molecular structure of $\mathrm{NiL}_{3} \cdot\left(\mathrm{ClO}_{4}\right)_{2}$ is shown in Fig. 1. It is easy to see that the center nickel(II) ion is coordinated with six $\mathrm{N}$ atoms of the three diacetyl dihydrazone and shows a distorted octahedral geometry. As shown in the molecular packing diagram (Fig. 2), there are positive negative charge interactions between $\left[\mathrm{NiL}_{3}\right]^{2+}$ cation and and $\mathrm{ClO}_{4}^{-}$. 
TABLE-2

SELECTED BOND LENGTHS $(\AA)$ AND BOND ANGLES $\left({ }^{\circ}\right)$

\begin{tabular}{cccccc}
\hline Bond & Length & Angle & $\left({ }^{\circ}\right.$ & Angle & $\left({ }^{\circ}\right)$ \\
\hline Ni-N(1)\#1 & $2.076(2)$ & $\mathrm{C}(1) \# 3-\mathrm{C}(1)-\mathrm{C}(2)$ & $120.57(15)$ & $\mathrm{N}(1) \# 1-\mathrm{Ni}-\mathrm{N}(1)$ & $96.11(11)$ \\
$\mathrm{Ni}-\mathrm{N}(1) \# 2$ & $2.076(2)$ & $\mathrm{N}(1) \# 1-\mathrm{Ni}-\mathrm{N}(1) \# 2$ & $166.87(11)$ & $\mathrm{N}(1) \# 2-\mathrm{Ni}-\mathrm{N}(1)$ & $94.16(7)$ \\
$\mathrm{N}(1)-\mathrm{C}(1)$ & $1.287(3)$ & $\mathrm{N}(1) \# 2-\mathrm{Ni}-\mathrm{N}(1) \# 3$ & $96.11(11)$ & $\mathrm{N}(1) \# 4-\mathrm{Ni}-\mathrm{N}(1)$ & $166.87(11)$ \\
$\mathrm{N}(1)-\mathrm{N}(2)$ & $1.369(3)$ & $\mathrm{N}(1)-\mathrm{C}(1)-\mathrm{C}(2)$ & $124.2(2)$ & $\mathrm{C}(1) \# 3-\mathrm{C}(1)-\mathrm{C}(2)$ & $120.57(15)$ \\
$\mathrm{CL}-\mathrm{O}(1)$ & $1.399(4)$ & $\mathrm{O}(2)-\mathrm{CL}-\mathrm{O}(1)$ & $108.05(16)$ & $\mathrm{O}(1)-\mathrm{CL}-\mathrm{O}(2) \# 7$ & $109.04(15)$ \\
\hline
\end{tabular}

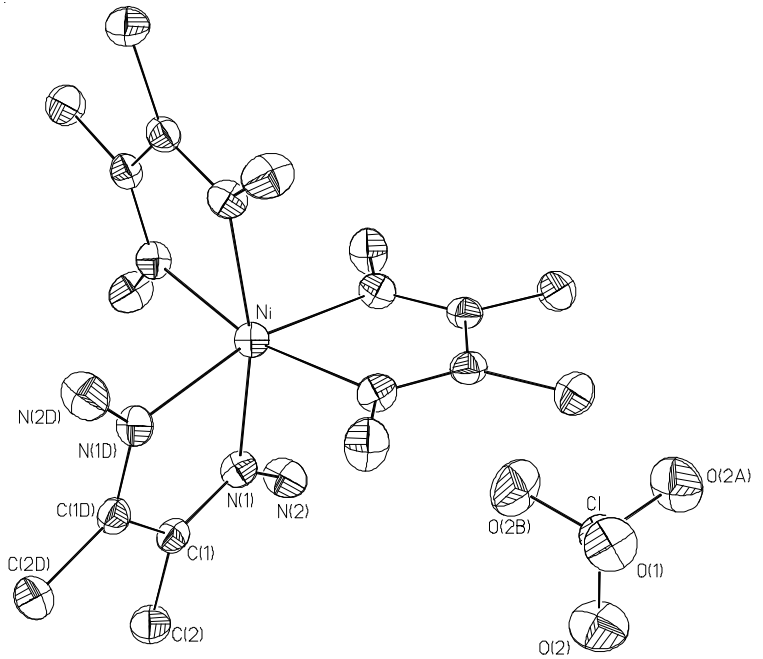

Fig. 1. Molecular structure of the complex $\mathrm{NiL}_{3} \cdot\left(\mathrm{ClO}_{4}\right)_{2}$

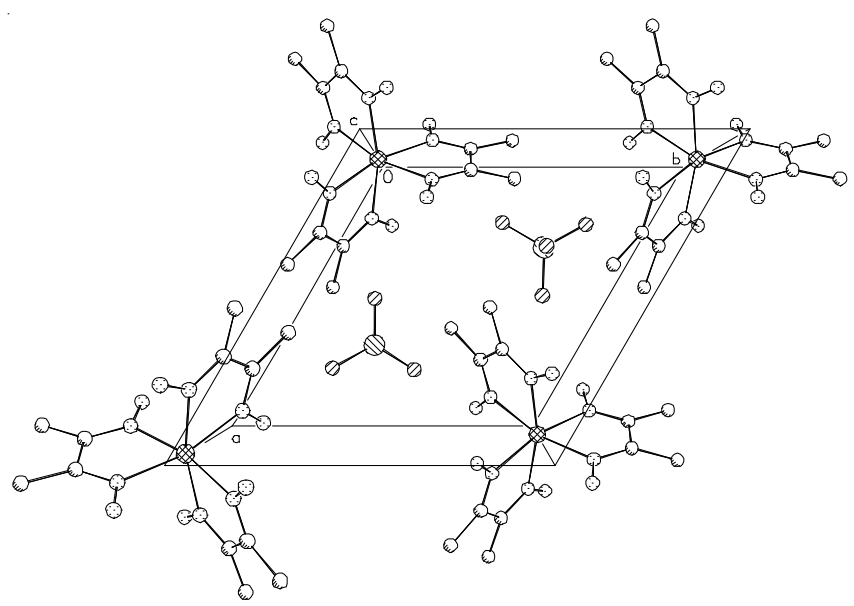

Fig. 2. Molecular packing arrangement in the unit cell

\section{ACKNOWLEDGEMENTS}

This work is financially supported by the National Natural Science Foundation of China (Nos. 20871039 and 21101053), the Natural Science Foundation of Anhui Province (Nos. 1308085MB23) and the Natureal Science Foundation of Anhui Universities (KJ2011Z301).

\section{REFERENCES}

1. O. Pouralimardan, A.C. Chamayou, C. Janiak and H. Hosseini-Monfared, Inorg. Chim. Acta., 360, 1599 (2007).

2. Y.H. Zhang, L. Zhang, L. Liu, J.X. Guo, D.L. Wu, G.C. Xu, X.H. Wang and D.Z. Jia, Inorg. Chim. Acta, 363, 289 (2010).

3. B.K. Rai, V. Singh, S.N. Vidyarthi and P. Sinha, Asian J. Chem., 23, 4638 (2011).

4. M. Hussain, Z. Shafiq, M.H. Nawaz, M.A. Shad, H. Nawaz, M. Yaqub and H.B. Ahmad, Asian J. Chem., 25, 2668 (2013).

5. S. Rollas and S.G. Küçükgüzel, Molecules, 12, 1910 (2007).

6. N.H. Al-Sha'alan, Molecules, 12, 1080 (2007).

7. A.K. Freidig and I.L. Goldman, J. Am. Soc. Hort. Sci., 136, 54 (2011).

8. D.H. Busch and J.C. Bailar, J. Am. Chem. Soc., 78, 1137 (1956). 